\author{
Aleksander Cywiński \\ Instytut Pedagogiki, Uniwersytet Szczeciński \\ E-MAIL: aleksander.cywinski@usz.edu.pl ORCID: oooo-0oo2-3945-9607
}

Problem polskich partii politycznych polega przede wszystkim na tym, że nie angażuja obywateli. Proszę zwrócić uwage, że one zazwyczaj działaja od wyborów do wyborów, ale na co dzień ich ramach nie odbywa się w zasadzie żadna poważna dyskusja o kondycji państwa, perspektywach rozwojowych i potrzebach obywateli. Polskie partie maja wielkie budżety i rozbudowane struktury, a jednocześnie stosunkowo niewielu członków i mało demokratyczną strukturę

Adam Bodnar, RPO (2020, s. 117)

\title{
Opowieść o tym, jak się stałem politycznym aktywistą
}

\section{STRESZCZENIE:}

Zamierzam opowiedzieć o tym, w jaki sposób stałem się politycznym aktywistą. Co spowodowało, że wyszedłem na ulicę, a więc naruszyłem pewne taboo: zaangażowania politycznego? Stawiam tezę, że w obecnym systemie politycznym zohydza się udział w życiu politycznym, tak aby pozostało to domeną wąskiej i stałej grupy obywateli, którzy czerpią w ten sposób zyski (w różnych wymiarach) kosztem reszty społeczeństwa. Mówię/piszę o tym, jak wchodziłem w interakcjami z innymi mieszkańcami Szczecina i czym to doświadczenie dla mnie było. Nie zamierzam nikogo przekonywać do tzw. „mojej opcji politycznej”. Ja przekonuję do tego, że należy się zaangażować, że to jest etap do pełni człowieczeństwa.

SŁOWA KLUCZOWE: polityka, obywatelstwo, demokracja, zaangażowanie

We wstępie chciałbym przekazać kilka uwag o charakterze światopoglądowym. Zmiany są konieczne. Nie ma jednak upragnionych zmian bez zaangażowania. Oczywiście, chciałbym, by było inaczej, ale zwykle bywa tak, że wszelkie zmiany, których doświadczałem w życiu, a nie były z mojej inicjatywy, przynosiły cierpienie. Samemu trzeba wywalczyć (niekoniecznie w pojedynkę, ale na pewno przez uczestnictwo).

No dobrze, może odrobinę przesadzam. Ale tak to widzę. A raczej pamiętam. I to będzie opowieść wygrzebana z mojej pamięci. Pierwszy raz spisana. Tylko dla waszych oczu. Ekskluzywna. Jednorazowa. Unikalna. Zapnijcie pasy, zabieram Was w opowieść o tym, jak stałem się robotnikiem demokracji, ulicznym aktywistą albo buntownikiem w imię praworządności. Kimś, 
kto posłuchał Arystotelesa i jego opowieści o człowieku jako zwierzęciu politycznym (2001, s. 76-79).

Aaa, pamiętajcie, z opowieścią nie ma żartów, skoro Jonathan H. Turner stwierdzał: „Teorie to opowieści o tym, jak i dlaczego następują wydarzenia. Teorie socjologiczne są przeto opowieściami o tym, jak ludzie się zachowują, wchodzą w interakcje i organizują" (Turner, 2004, s. 1). Odwracając: opowieść może być teorią, a więc tak jak ona wyjaśniać. Kto ma uszy, niech słucha.

Rok 2020 był rokiem przełomu pod każdym względem. No dobrze, może znów odrobinę przesadzam, ale zdecydowanie był to rok, który zapamiętamy. Również ze względu na wybory prezydenckie. Pisanie o tym, oprócz wymiaru poznawczego, ma również terapeutyczny, albowiem ta opowieść wynika z potrzeby domknięcia i poszukania sensu, ponieważ dopiero pisząc te słowa uświadamiam sobie pewne sensy, a więc to, że wtedy przekroczyłem próg przygody (Pannebaker i Smyth, 2018, s. 178-179).

Nim przejdę do opowieści o mojej politycznej przygodzie, muszę odrobinę powiedzieć o sobie. W zasadzie odrobinę lubię taką sytuację, ale również odrobinę nie lubię. I właśnie taki dualizm, a więc stwierdzanie: „jestem trochę taki, i trochę taki”, jest moją cechą. To pierwsza część opowieści o mnie. Kolejną zaczerpnę z książki Josepha Campbella Kwestia bogów. Campbell używa metafory drabiny przystawionej do ściany. Każdy człowiek ma swoją drabinę i swoją ścianę. Wspina się po niej. Rzecz w tym, by ustawić drabinę przy właściwej ścianie. Konsekwencją ustawienia drabiny przy niewłaściwej ścianie jest uczucie, że jest się wykorzenionym (Campbell, 1994, s. 11-13). I co mnie jeszcze przekonuje do Campbella, to, że tak pięknie wplótł w swój wywód cytat z Dantego:

W życia wędrówce, na połowie czasu, straciwszy z oczu szlak nieomylnej drogi, w głębi ciemnego znalazłem się lasu (Dante, 1990, s. 25)

Czy tak się czuję? Że postawiłem swoją drabinę przy niewłaściwej ścianie i w połowie życia czuję się zagubiony? I tak, i nie. Ta nieumiejętność jednoznacznej odpowiedzi, wynika z tego, że mówię o procesie, który jest w toku. Są bowiem tacy magicy $\mathrm{w}$ przestrzeni publicznej, którzy przebudowują ścianę, przy której postawiłem swoją drabinę. Moją ojczyznę. Cegła po cegle zmieniają jej strukturę. Więc sprawa jest skomplikowana.

Chcę wyrazić się jasno, mam na myśli zmiany ustrojowe, których doświadczamy w naszym kraju od kilku lat. Stawiałem swoją drabinę w momencie obowiązywania Konstytucji z 1997 roku. Obecnie czynione są zamachy na jej ducha. W rezultacie, jest reakcję na to co się dzieje, swój stan psychiczny 
za Campbellem określam jako „nocne morze”. W sytuacji kryzysu jest to zejście: „we własną głębinę, by odnaleźć zapomnianą, pominiętą energię, która powinna była przenikać nasze życie, ale została wyeliminowana przez postawę świadomą" (Campbell, 1994, s. 87).

Widząc co się w kraju dzieje, zanurzyłem się, i zrozumiałem, że Patria mnie potrzebuje, wzywa. Że zbyt długo uchylałem się od powinności, jaką jest zaangażowanie społeczno-polityczne. Czy dacie wiarę? Słyszałem ten głos zarówno w samotności, jak i będąc pośród tłumu na gwarnych ulicach.

Istotne dla opowieści jest to, że moje życie dzieje się w mieście, czyli największym dziele człowieka, a jednocześnie hiper katalizatorze twórczej aktywności (Kotkin, 2018, s. 22). I moje miasto, Szczecin, jest dla mnie jak matka, która do mnie mówi. Tu znów kłania się Campbell, który wskazuje, że miasto może być wyobrażeniem matki. Stwierdza: „Miasto otoczone murami jest naszą matką, matką cywilizacji, matką życia. A więc kultura jest naszą matką" (Campbell, 1994, s. 54). Miasto jest więc areną dla tej opowieści. Miasto mnie wtedy połknęło, niczym ogromny stwór, a ja poruszałem się w jego wnętrzu. Mogę więc dodać, że nie tylko Patria, ale i Polis wzywała mnie do działania jak nigdy dotąd. Łączy się to ze średniowiecznym prawem, które stanowi, że powietrze miejskie czyni wolnym. Tak, czyni, ale trzeba walczyć, by prawo to było respektowane przez feudalnych panów.

W swej opowieści, na tyle ile umiem, wzoruję się na Mario Vargasie Llosie, który w swej książce Jak ryba w wodzie opisał swoje życie oraz udział w kampanii prezydenckiej w Peru roku 1990. Noblista, na wieść o upaństwowieniu systemu finansowego (czytaj: położeniu „łapy” przez rządzących na prywatnych aktywach), stwierdził:

I znowu Peru wykonało krok w kierunku barbarzyństwa. [...] Zapowiedziana nacjonalizacja wniesie jeszcze więcej biedy, przygnębienia, pasożytnictwa, przekupstwa do życia Peruwiańczyków. I prędzej czy później zniszczy system demokratyczny, który Peru odzyskało w 1980, po dwudziestu latach dyktatury wojskowej (Llosa, 2010, s. 41).

Skracając, wielki pisarz, zdecydował się ubiegać o urząd prezydencki w swej ojczyźnie. Niestety, nieskutecznie. Ale słyszał ten głos. Głos wzywający do przygody, który jest motorem opowieści.

Llosa jest niezwykle uczciwy w tym co pisze. Wspomina, że gdy był pytany o to, dlaczego zamierza starować w wyborach, porzucając przy tym względnie wygodne życie, powoływał się na interes kraju i powinność służenia mu. Zaraz jednak dodawał, że na głębszym poziomie, prawdziwsze były słowa jego żony, która zauważyła, że pociągała go chęć przeżycia przygody. Llosa stwierdza: 
nie wykluczam, że w ciemnej otchłani [czyżby chodziło o zanurzenie się w „nocne morze" - wtrącenie A.C.], skąd biorą początek nasze czyny, tkwiła raczej pokusa przeżycia przygody niż jakikolwiek altruizm, który mógłby popchnąć mnie do zawodowej polityki (Llosa, 2010, s. 52).

Chodziło zatem o pokusę przeżycia przygody. Ale może Patria i Polis właśnie do tego mnie wzywają swym nawoływaniem? Może z tego rodzą się owe szacowne i nobliwe instytucje? Z przygody. Może tak powstał nasz kraj? Może tylko dzięki temu przetrwa? Że jego obywatele będą mieli odwagę przeżyć przygodę.

Myślę, że jestem względnie świadomym obserwatorem życia politycznego. Krajowego oraz światowego. Od 2015 roku, od wygranych przez Prawo i Sprawiedliwość wyborów prezydenckich i parlamentarnych, starłem się uważnie obserwować co się dzieje. Tak, obserwować. Dałem kredyt zaufania albo wykazywałem jakąś obojętność na to co się dzieje. Ale pojawił się temat Trybunału Konstytucyjnego. Konflikt wokół tej instytucji. Coraz mocnej czułem, że rządzący mają pęd, by sięgać po niezgodne z prawem rozwiązania. Zwykle szybko sobie jednak tłumaczyłem, że druga strona nie była lepsza. Że też „majstrowała”. Wiadomo, politycy i ich odwieczne pokusy, by posługiwać się narzędziami, które nie są dozwolone.

Stopniowo marginalizowałem w mojej głowie znaczenia polskiej polityki. Skupiłem się na tym co zagraniczne, co bardziej uniwersalne. Patrzyłem na polską politykę jak na zamieszanie w kurniku, w którym jest kilka kogutów, które muszą rozstrzygnąć, który z nich przewodzi. Pytałem sam siebie, czy interesują mnie walki kogutów i mówiłem, że nie.

23 czerwca 2016 roku odbyło się referendum brexitowe. Wynik mnie zaszokował. Ale podniosłem się. Pozbierałem. I dalej naiwnie ufałem w racjonalność oraz przewidywalność polityki międzynarodowej. Dalej za Francisem Fukuyamą uważałem, że demokracja liberalna jest numer jeden, mimo chwilowych zawirowań (Fukuyama, 2009). Ale 8 listopada 2016 wybrany został 45 prezydent Stanów Zjednoczonych - Donald Trump. I poczułem, że coś definitywnie się zmienia. To jakby odroczone skutki kryzysu finansowego z 2008 roku. Okazało się, że słowo „postprawdziwy” („odnoszący się do lub cechujący okoliczności, w których obiektywne fakty w mniejszym stopniu wpływają na kształtowanie opinii publicznej niż odwołanie się do emocji i osobistych przekonań") zrobiło w tym czasie zawrotna karierę. Było używane 2 tysiące procent częściej. Sprawiedliwie zostało uznane za słowo roku 2016 (Czarnecki, 2016). To już nie jest czas racjonalności, to czas emocji. Złych.

Nadto, coraz mocniej dochodziły do mnie, do mojego skrytego wnętrza, głosy wybitnych polskich prawników: 
Nie jest to już ten Trybunał Konstytucyjny o którym jest mowa w konstytucji. Pani Przyłębska z punktu widzenia konstytucji nie jest jego prezesem (Andrzej Zoll, za: Mikulski, 2017),

Chciałbym rozpocząć od takiego wezwania do wszystkich parlamentarzystów, którzy podpisali ten projekt ustawy o likwidacji Sądu Najwyższego, żeby jeszcze raz go przeczytali. Bo może się podpisali, nie bardzo sobie zdając sprawę, co jest w środku. Lista tych posłów, którzy świadomie podpisali się pod tym projektem, to będzie kiedyś lista hańby (Adam Strzębosz, za: Malinowski,2017),

To, co się stało ostatnio w naszym kraju, uchwalenie dwóch ustaw odnoszących się do judykatywy, czyli do sądownictwa i zapowiedz nowej ustawy, pojawiającej się w Sejmie nagle, nikomu nieznanego projektu ustawy dotyczącej Sądu Najwyższego, jest bardzo niepokojące [...]. Władza sądownicza zgodnie z tymi trzema ustawami, dwie uchwalone, trzecia zapowiedziana, zostałaby podporządkowana egzekutywie, czyli władzy wykonawczej. Dlatego, że minister sprawiedliwości, będący jednocześnie prokuratorem generalnym, miałby wpływ, poprzez KRS, na obsadę sądów, na to jak się załatwia awans sędziowski (Ewa Łętowska, za: Oko. Press, 2017).

Jestem prawnikiem z wykształcenia i nie mogłem dłużej udawać, że jest ok. Czarę goryczy przepełnił tekst Andrzeja Gomułowicza pod tytułem Oblicze polskiej dyktatury (2019). Padają tam następujące słowa:

W Polsce nastaje czas przemian niezwykłych i bezprecedensowych. Dokonuje się przejście z systemu prawnego państwa demokratycznego do systemu autorytarnego (s. 7o) [...]. Nowy, tworzony w nocnym trybie ład prawny, w zasadniczym nurcie niekonstytucyjny, nie ma służyć państwu, a partii (s. 71) [...]. Zaciera się granica między dobrem partii a dobrem państwa" (s. 72) [...]. W Polsce funkcja prezesa PiS została przekształcona w najważniejsze stanowisko w państwie. Jego wola ma moc prawa. Zatarta jest granica między wolą prezesa PiS a wolą państwa. Prezes uzyskał pełnię władzy niczym nieograniczonej. Dla Konstytucji nie czuje respektu, faktycznie bowiem usadowił się ponad nią. Nie jest Konstytucją związany. Arbitralnie przesądza o tym, co stanowi polską rację stanu (s. 75).

Zatem słowa Zolla, Strzębosza, Łętowskiej, Gomułowicza, a więc doświadczonych prawników, układały się w opowieść o moim kraju, w którym następuje demontaż trójpodziału władzy, czyli jądra demokracji. Zrozumienie tego sprawiało, że nie mogłem usiedzieć spokojnie w miejscu. Nie dało się bezczynie czekać na dalszy bieg wypadków. Docierało do mnie, że stopniowo przestaję być obywatelem, a zamieniam się w gotowaną w garnku żabę. A to już sytuacja jak z Przemiany Kafki.

Z tamtego czasu, wzrastającego lęku, chciałbym jeszcze wyróżnić erudycyjną książkę Krzysztofa Mroziewicza Delirium władzy (2019), z której płynął następujący wniosek: na świecie dzieje się źle. 
Paradoksalnie, ponieważ nieświadomie, a jednocześnie z niepokojem, czekałem na znak. Pierwszy dotarł do mnie we wrześniu 2019 roku. Słuchałem radia. Transmitowana była w nim uroczystość, podczas której ogłaszano kandydaturę Y, przedstawicielki największej opozycyjnej partii, na fotel prezydencki. I im dłużej jej słuchałem, tym bardziej do mnie dochodziło, że nie ma ona szans. Żadnych.

Drugim był telefon od znajomej osoby w październiku 2019 roku. Pytała mnie ona czy kojarzę X, czy są mi w jakieś sposób bliskie jego poglądy i czy ewentualnie byłbym gotów włączyć się w jego projekt polityczny. Powiedziałem: tak. Potem dostałem informację, że X przyjedzie na spotkanie do Szczecina i będzie chciał przedstawić swoją propozycję.

Spotkanie odbyło się na początku listopada. To była niewielka sala. Około 30 osób. Część znałem, część kojarzyłem, część była mi obca. Czekaliśmy na przybycie X. Stałem akurat na korytarzu, i jak to ja, korzystałem ze skromnego, ale smakowitego poczęstunku. Gdy zobaczyłem X idącego korytarzem, pomyślałem: o, typ długodystansowca. Wysoki, szczupły, idący bez wysiłku pomimo, że przed chwilą wspiął się po schodach. Ktoś wytrzymały, kto jest w stanie długo i efektywnie pracować.

Spotkanie się rozpoczęło. Jako, że zwlekałem z wejście do sali, miejsce było już tylko w pierwszym rzędzie. Na szczęście lubię miejsca w pierwszym rzędzie. Dobrze widać, słychać i można wyciągnąć nogi. X zaczął przemawiać. Powiedział, że chce wystartować w wyborach prezydenckich. Bardzo się zdziwiłem. Słuchałem jednak. Zaczął od tego, że obecnie dla niego tematem numer jeden jest ekologia. Pomyślałem, że dla mnie też. Im dłużej mówił, przedstawiając główne założenia swego programu, tym bardziej jego pomysł mi się podobał.

Nowość, świeżość, energia, inteligencja X, którą zobaczyłem podczas jego godzinnej przemowy, siedząc 2 metry od niego, przekonała mnie. X skończył mówić. Pamiętam, że pomyślałem wtedy: „A w sumie czemu nie?”. Dotarło do mnie, że chcę zaryzykować. Teraz wiem, że to konieczna cześć przygody. Decyzja o rozpoczęciu podroży musi być poprzedzona takim aktem. Inaczej się nie da. Gdy nie ma ryzyka, świadomości, że coś trzeba poświęcić, sprawa zamienia się emocjonalnie w coś na poziomie wizyty w centrum handlowym. Totalnie jałowego zajęcia, podczas którego wszyscy próbują wcisnąć coś, co nie jest potrzebne.

Zapadła cisza. Zacząłem bić brawo. Inni się przyłączyli. X powiedział, że bardzo nam dziękuje. Teatralnie szepnąłem do niego, że ja byłem pierwszy. On równie teatralnie odparł, że widział i czy może być w zamian stanowisko ambasadora w Ułan Bator. Odparłem, że oczywiście i uradowało mnie, że 
facet ma jeszcze do tego poczucie humoru. Zdecydowałem, że zaangażuję się. Że jeden raz w życiu trzeba tak postąpić. Po prostu przeżyć polityczną przygodę. Bez względu na rezultat i konsekwencje. Że potrzebuję tego, by pełniej być istotą społeczną.

$\mathrm{X}$ poprosił nas na zakończenie, tych którzy zdecydowali się przyłączyć, o to, byśmy poczekali na sygnał do działania. Zacząłem wypytywać znajomych o to, co myślą na temat ewentualnego startu X w wyborach prezydenckich. Czy byliby skłonni na niego zagłosować? Przeważały pozytywne głosy. Czekałem zatem.

W grudniu 2019 roku X publicznie ogłosił, że zamierza wystartować. $\mathrm{Z}$ mej strony zaczął się czas niecierpliwości. Marzyłem o tym, by działać, a tu cisza. Ale przyszedł ten moment, początek lutego 2020 roku. Potrzeba było zebrać 100 ooo podpisów, by X mógł kandydować. To chyba było 7 lutego, gdy wyszliśmy pierwszy raz na miasto. Uwaga: uważajcie, bo marzenia się spełniają. Marzenie przerodziło się w marznięcie. Odkryłem, że mimo ocieplenia klimatu i kalesonów, kilkugodzinne stanie na ulicy w lutym i marcu jest zajęciem przykrym. Przyjąłem zatem określoną strategię. Stać około dwóch godzin, w znanym sobie terenie. I nie brać do siebie krytycznych uwag na temat $\mathrm{X}$, które wypowiadali zaczepiani ludzie.

Bo tak to wyglądało. Zaczepiałem ludzi, a ci mi odpowiadali na różne sposoby. Wołałem do nich i za nimi. Okazało się, że wcale nie jest tak łatwo zdobyć te podpisy. Byłem wtedy dwoma osobami. Grałem teatr, w którym jeden Alek omal żebrał o każdy podpis, a drugi obserwował i myślał o... no właśnie, o czym ja wtedy myślałem?

To było takie ajschylosowskie. Rozmowa, czasem gwałtowna dwóch aktorów, którzy rezydują w jednej głowie. Dramat rozpisany na kwestie o tym, jak trudne jest życie ludzi, których los jest zależny od czyjejś dobrej albo złej woli. Którzy każdego dnia muszą się mierzyć $\mathrm{z}$ agresją, pogardą i niepewnością. Którzy są zostawieni samymi sobie. Za którymi nie stoi ktoś, kto ich wesprze. O tych co marzną i chce im się siku, ale nie mają gdzie załatwić swoich potrzeb fizjologicznych. O bezdomnych, chorych, niepełnosprawnych, w jakikolwiek sposób innych, a przez to wykluczonych. O sprawiedliwości i jej wrednej siostrze: niesprawiedliwości. To przedziwne, ile myśli może przebiec przez głowę podczas takiego stania. Fizycznie, prawie się nie przemieszczałem, ale mentalnie byłem w „nocnym morzu”. Nawet jeśli ktoś do mnie mówił, nawet gdy ja mówiłem. Więc zbieranie podpisów było ponadmiesięczną podróżą w głąb samego siebie. Myślę, że potem już byłem trochę innym człowiekiem.

Chcę napisać o jednym spotkaniu podczas zbierania podpisów. Zaczepiłem chłopaka, lat około 30. Mówię o co chodzi i zaczynam wyczuwać, że ten 
jest pod wpływem alkoholu. Trochę żałuję, ale nie ma odwrotu. A on zaczyna mówić. Długo i gwałtownie. Okazuje się, że jak najbardziej popiera X i jest zmęczony tym co dzieje się w kraju. Wie, że potrzebna jest zmiana. Wyrzuca swoje żale. Nawet jeśli jest to momentami pełne przekleństw, to wsłuchując się w to co mówi, dostrzegam, że to jest również moja ocena sytuacji, tylko ubrana w inne słowa. Żegnamy się. On po 20 minutach wraca. Niesie karton z pizzą. Mówi, że ja tu marznę, a on mi w ten sposób chce mi podziękować za pracę. Proponuję, byśmy zjedli wspólny posiłek. No i jemy. W tym zimnie, brudnymi rękoma, pomimo tłumu, który nas mija. A mi wraca wiara w człowieka, solidarność, proste, ludzkie gesty.

Potem przyszedł przedziwny czas pierwszego lockdownu. Od połowy marca. Nasza aktywność przeniosła się do internetu. X codziennie miał kilka wystąpień w mediach społecznościowych. Jego popularność stopniowo rosła. Wyraźnie było widać, że radzi sobie najlepiej ze wszystkich kandydatów w takim środowisku.

Ja tymczasem zostałem poproszony o pomoc w jednym ze szczecińskich domów dziecka przy odrabianiu lekcji. Obserwowałem dramat podopiecznych zamkniętych na niewielkiej powierzchni. Dzieci te próbowały rozpaczliwie wypełnić swój obowiązek szkolny, ponieważ pan minister nie „odchudził" podstawy programowej. Wpadłem na pomysł, że z napięciami, jakie się rodziły na skutek zamknięcia i natłoku zajęć, będziemy radzić sobie przez ćwiczenia fizyczne. Przyznam, że już dawno tyle nie ćwiczyłem. Niech to będzie miarą tego, co przechodziły te dzieci. Byłem tam w kwietniu i maju.

A, i jeszcze jedno, jadłem, dużo jadłem, właśnie w domu dziecka. A konkretnie po dzieciach. Nie mogłem bowiem patrzeć, jak wyrzucają jedzenie. Rozumiem, że akt ten mógł być formą buntu wobec sytuacji, w której się znajdują, może skutkiem wyobrażenia, że dziecko w normalnej rodzinie właśnie tak postępuje, albo przejawem zaburzeń łaknienia na skutek traumatycznych przeżyć. Nie wiem tego. Nie pytałem. W każdym bądź razie dzieci patrzyły na to początkowo z obrzydzeniem. Sytuacja jednak szybko się zmieniła. Zaczęły mi w tym kibicować. Może dlatego, że rozumiały, że jestem tu tylko na chwilę i muszę nabrać sił do lotu. O czym ja nie zdawałem sobie sprawy, ale widać one rozumiały znaczenie więcej. Po dwóch miesiącach intensywnego ćwiczenia i jedzenia byłem gotów. To znaczy moje ciało było. Bo ja jeszcze wtedy nie byłem świadomy tego, że ponownie wyjdę na ulicę.

Działy się w tych dniach rzeczy przedziwne. Urzędujący prezydent rapował o ostrym cieniu mgły (Duda, 2020), 10 maja 2020 roku nie odbyły się wybory, ponieważ Państwowa Komisja Wyborcza uznała, że nie ma kandydatów (uchwała nr 129/2020 Państwowej Komisji Wyborczej z dnia 10 maja 
2020 r.), a partia rządząca umożliwiała największej partii opozycyjnej podmianę kandydata (ustawa $\mathrm{z}$ dnia 2 czerwca 2020 r.). Rząd zaś serwował nam kolejne bezsensowne zagrania. Szczytem było zamknięcie lasów. Jeżeli ktoś miał jeszcze wątpliwości, kto nami rządzi, to był to chyba ostateczny dowód ich partactwa, które zapamiętam przede wszystkim dzięki podkrążonym oczom pewnego ministra, który jak się później okazało, był mocno zajęty poprawą kondycji finansowej swej rodziny (Piątek, 2020, s. 48-50). Podsumowując, gdyby jeszcze wylądowało UFO, po prostu wzruszyłbym ramionami i zapytał: no i co z tego.

My, sympatycy X, dowiadując się, że wybory odbędą się 28 czerwca 2020 roku, spotkaliśmy się i podzieliliśmy zadaniami. Stanąłem w ten sposób do drugiej akcji ulicznej. Zdecydowałem się bowiem ponownie wyjść w miasto i namawiać w ten sposób do głosowania na X. Za miejsce swej pracy obrałem plac Grunwaldzki. Codziennie zakładaliśmy tam nasz obóz, rozkładając maszt i stolik z materiałami reklamowymi.

Muszę również wspomnieć o moim rowerze, którym przewoziłem cały ten majdan, bywało, że po kilkadziesiąt kilogramów. Do tego mocowałem do niego mobilny baner z X i stawiałem w widocznym dla kierowców miejscu. To przedziwne, ale w tym czasie, myślałem o nim jako o omal żywym stworzeniu, które wiernie służy tej samej sprawie co ja.

W tych dniach, czerwcowego upału, ze względu na wykonywaną wielogodzinną fizyczną pracę, zacząłem definiować samego siebie jako robotnika demokracji. Na marginesie: przyjąłem konwencję, że podobnie jak robotnik ma swój strój, tak i ja będę miał. Nie rozstawałem się zatem ze słomkowym kapeluszem, do którego przywiązałem kawałek materiału w kolorach naszego ruchu, kampanijnej koszulki, krótkimi spodenkami i sandałami. Byłem, wobec tego, kimś, kto wstaje wcześnie rano, załatwia tak szybko jak się da swoje sprawy zawodowe związane z pracą na uczelni i leci na ulicę, by przekonywać ludzi do określonej idei. Nic dziwnego, że wielokrotnie byłem pytany o to, ile mi za to płacą. Pytano, ponieważ zwłaszcza wieczorem, byłem tak zmęczony, że ledwo stałem na nogach. Dla ludzi z zewnątrz, jedynym racjonalnym wytłumaczeniem takiej postawy było to, że ja się bogacę na kampanii. Starałem się grzecznie tłumaczyć, że tak nie jest.

Ja jednak leciałem dla idei (piszę „leciałem”, ponieważ byłem w stanie uniesienia) i śpiewałem w duchu słowa Ducha z III Części Dziadów:

Człowieku! gdybyś wiedział jaka twoja władza! Kiedy myśl w twojéj głowie, jako iskra w chmurze Zabłyśnie niewidzialna, obłoki zgromadza, I tworzy deszcz rodzajny, lub gromy i burze; Gdybyś wiedział, że ledwie jednę myśl rozniecisz, Już 
czekają w milczeniu, jak gromu żywioły, Tak czekają twej myśli - szatan i anioły: Czy ty w piekło uderzysz, czy w niebo zaświecisz; A ty, jak obłok górny ale błędny, pałasz, I sam nie wiész gdzie lecisz, sam nie wiész co zdziałasz... Ludzie! każdy z was mógłby, samotny, więziony, Myślą i wiarą zwalać i podźwigać trony (Mickiewicz, 1984, s. 20).

Naprawdę, głęboko wierzyłem, że X może wygrać. Siłą naszej, uwspólnionej woli.

Wracając do opowieści, podobnie jak przy zbieraniu podpisów, zaczepiałem ludzi. Pocieszające było to, że wzrosła rozpoznawalność X. Nadal jednak spotykałem się z aktami agresji. Pamiętam mężczyznę, który wyrwał mi ulotkę, pogniótł i rzucił na ziemię. Pamiętam typa, który chciał mnie pobić, ale był tak pijany i cztery razy wolniejszy ode mnie, że bałem się, iż się potknie o swoje nogi i będzie na mnie, że go pobiłem. Wspominam starszego pana, który krytycznie wypowiedział się o X, a następnie, z niezrozumiałych względów, wskazał, że ma wyższe wykształcenie (ten pan), a potem zapytał, jakie mam ja i chyba jednak mi nie uwierzył, gdy mu powiedziałem.

Zaczepiłem setki, a może tysiące ludzi. Ale robiłem również inne rzeczy. Byłem na przykład współrozklejającym plakaty na słupach ogłoszeniowych udostępnionych w tym celu przez miasto. Pewnie właśnie z tej przyczyny, ponieważ było to dość ciężkie zajęcie, tak mnie zdenerwowało, gdy odkryłem, że na plakatach przedstawiających X, wiszą plakaty Z, kandydata największej partii opozycyjnej. Zresztą nie tylko X został zaklejony. Wszyscy kandydaci. Odebrałem to jako akt skrajnej pychy. Coś niesprawiedliwego. Te słupy ogłoszeniowe były przecież wspólne. Każdy kandydat miał do nich prawo. Należało się podzielić przestrzenią.

Zrobiłem zdjęcie przedstawiające ten proceder. Zaczęło ono „żyć” w mediach społecznościowych. W komentarzu wyczytałem, że nie ma co robić afery i dzielić opozycji, bo i tak $\mathrm{Z}$ ma największe szanse, by wygrać, a poza tym, to pewnie jedna i ta sama ekipa klei te plakaty. Ostatecznie dotarło do mnie, że w polityce wszystkie chwyty są dozwolone. Resztką sił, na trzy dni przed wyborami, ponownie nakleiliśmy plakaty, dokładnie w te same miejsca, gdzie wisiały poprzednio.

I pamiętam ten moment. Piątek wieczorem. 26 czerwca 2020 roku. Koniec kampanii ze względu na ciszę wyborczą. Około godziny 23 postanowiłem jeszcze przejechać się rowerem po mieście. Niby bez powodu. Ale miałem po prostu przeczucie. Na jednym ze słupów ogłoszeniowych w centrum miasta znów zobaczyłem plakaty Z. Sytuacja się powtórzyła. Zagotowało mnie. Jeździłem od słupa do słupa i na każdym była identyczna sytuacja. W końcu 
przy jednym z nich zobaczyłem samochód i kilku mężczyzn. Pomyślałem: mam was! Było ich czterech. Podjeżdżam. Pytam od kogo są. Oni mi mówią, że od B. A więc nie Z. Zaczynają się przede mną tłumaczyć, są wyraźnie przestraszeni. Dostrzegam, że mają może po 20 lat. Zaczynamy dyskusję. Psioczymy razem na zachowanie ludzi Z. Żegnam się z nimi, życząc powodzenia. Odjeżdżam. I wtedy do mnie doszło jak daleko się posunąłem, skoro byłem gotów zaryzykować własne bezpieczeństwo. $\mathrm{Z}$ drugiej strony bawiło mnie to, jak byłem wiarygodny, skoro to oni się przestraszyli.

Nie będę się rozpisywał na temat samych wyników wyborów. Wtedy było to dla mnie strasznie ważne, teraz już mam chyba do tego dystans. Ważniejsza z punktu widzenia opowieści jest moja podróż. Świadomie używam tego terminu, choć w tym czasie w zasadzie nie opuszczałem mojego miasta. Była to jednak wyprawa pełna przygód, która w jakiś sposób wpisuje się w schemat przedstawiony przez Josepha Campbella w książce Bohater o tysiącu twarzy (1997). Nie twierdzę, że w 100\% odtworzyłem jego koncepcję monomitu, ale zatoczyłem koło. Na powrót siedzę w moje kuchni przy stole, patrzę przez okno, myślę i piszę. A jednocześnie jestem już innym człowiekiem. Końcem wyborczej podróży było napisanie i nagranie piosenki pod tytułem Boski. Odnosi się ona do polityków. Proszę, posłuchajcie jej (Chłopcy, 2020, 28 minuta 50 sekunda). Ale uwaga: słowa, jako całość, w warstwie politycznoironicznej odnoszą się do szefa rządzącej partii. Taki był cel tego pisania. Ale jednocześnie jakaś część mnie, chciała bym napisał również o stosunku do $\mathrm{X}$. Piszę w refrenie:

\author{
Tylko ty, taki boski \\ Taki mądry, taki na lata \\ Tylko ty taki wielki \\ Większy od reszty świata \\ Tylko ty, tak kuszący \\ Niczym kwiaty na skraju polany \\ Tylko ty taki mądry \\ I taki przemyślany
}

I jeżeli czytać refren nie w kluczu politycznym czy ironicznym, a relacji ludzkiej i swego rodzaju „zakochania” (nie w znaczeniu erotycznym), to gdzieś głęboko i trochę ze wstydem, ponieważ jest to opowieść o uczuciach (a jak wiadomo polski mężczyzna uczuć się wstydzi), a nie kampanijnych czynach, których dokonywałem na oczach miasta, mówię Wam o przestrodze, by nie traktować idola (w tym przypadku politycznego) jako boga, kogoś idealnego i omnipotentnego. Inaczej narażamy się (i słusznie) na śmieszność. $X$ jest zwykłym człowiekiem (ale ma do zaoferowania niezwykłą, bo poruszającą 
opowieść) i jak zwykły człowiek jest pełen wad (i mówi o tym otwarcie). Podstawową konsekwencją tego banalnego stwierdzenia jest taka, że jeżeli to jest istota ludzka, to nie załatwi naszych sprawa za nas. My to musimy zrobić.

Dostrzegam, że nie napisałem o wszystkim. Ooo... mógłbym napisać o tym jak X 19 lutego przyjechał do Szczecina, by zbierać podpisy i otworzyć nasze lokalne biuro. Nie dojadł wtedy pierogów, którymi został poczęstowany. Nie mogłem na to patrzeć. Że mogłyby pójść do kosza. I pysznego tortu też nie dojadł, bo go stale ktoś zagadywał. Potem wszyscy się śmialiśmy ze mnie. Bo zjadłem. Ale ja nie dbałem o to, bo czułem, że postępuję słusznie, a jednocześnie pokazałem im mój świat wartości. Że uważam, że jest coś ważniejszego niż ciągłe pielęgnowanie tego, jak jesteśmy postrzegani. A może ja stąd miałem takie siły? Moc do działania. Że obudziłem w sobie gotowość do transgresji. Opuszczenia konfrontowanego świata, w którym żyję, na rzecz przebycia licznych prób, zarówno w wymiarze psychicznym, jak i fizycznym. W imię wartości. Tak rozumiem Campbella (1997). I tak musi wyglądać opowieść o tym, jak się stałem politycznym aktywistą. Z pewnością można to przedstawić podług innego schematu. Ale to nie byłaby moja opowieść. Nie moja podróż.

Nie koncentruję się na X. Nie wymieniam nawet jego imienia i nazwiska, ponieważ nie ma to znaczenia. Równie dobrze mogłem być w ekipie Z, B, K. Być może też bym przeżył podobną podróż. Zdaje się, że Japończycy mawiają, iż wiele dróg prowadzi na szczyt góry Fuji. Skupiam się na tym czego sam doświadczyłem w związku z moim zaangażowaniem w jego kampanię. Ale nie jest to autoetnografia ewokatywna (Bochner i Ellis, 2016, s. 65). Tu nie ma tej szerokości patrzenia, tej wieloaspektowości. Tu wybiórczość jest celowo skoncentrowana na wątkach w zasadzie metafizycznych, eksponowaniu tego co trudno wytłumaczalne (wracający motyw jedzenia). Opowiadam o tym, jak na mnie wpłynęła opowieść X. Nic mniej, nic więcej. Mówię tym samym o interakcji, czyli kolejnym ogniwie w łańcuchu. Dobra opowieść rodzi opowieść. Prędzej, czy później. Fakt komunikacji jest najistotniejszy. To jest element myślenia samego siebie, tworzenia własnej tożsamości. Jean-Claude Kaufmann mówi: „sfera społeczna jako taka powstała w postaci narracji” (Kaufmann, 2004, s. 212). Jesteśmy, jako jednostki jednocześnie poddani dwóm, bywa, że przeciwstawnym procesom: spójności i ewolucji. Opanować można wynikające $z$ tego napięcia tylko poprzez snucie narracji, która nadaje znaczenie doświadczonym wydarzeniom (Kaufmann, 2004, s. 211-212).

Ja zdecydowałem się przyłączyć do X i stąd moja opowieść, którą musiałem utrwalić, aby pojąć co przeżyłem. W tym momencie mam nadzieję, że 
ktoś podejmie ten wątek. Zatem jaka jest twoja opowieść o zaangażowaniu politycznym? Czy masz już taką?

\section{BIBLIOGRAFIA}

Arystoteles. (2001). Dzieła Wszystkie, t. 6: Polityka, przeł. L. Piotrowicz. Kraków: PWN.

Bochner, A.P. i Ellis, C.S. (2016). Evocative Autoethnography. Writing Lives and Telling Stories. New York-London: Routledge.

Bodnar, A. i Bartosik, B. (2020). Obywatel.pl. Kraków: Mando.

Campbell, J. (1994). Kwestia bogów, przeł. P. Kosztyło. Warszawa: Jacek Santorski \& CO, Agencja Wydawnicza.

Campbell, J. (1997). Bohater o tysiącu twarzy, przeł. A. Jankowski. Poznań: Zysk i s-ka.

Chłopcy. (2020). Boski, płyta Ślady, wydane we własny zakresie. https://www.youtube.com/ watch?v=s7qEQQIohu8\&t=2011s [dostęp: 01.02.2021].

Czarnecki, M. (2016). Przymiotnik „postprawdziwy” słowem roku. Gazeta Wyborcza, 16 listopada. https://wyborcza.pl/7,75399,20984127,przymiotnik-post-prawdziwy-slowem-roku. html [dostęp: 27.01.2021].

Dante, A. (1990). Boska komedia, przeł. E. Porębowicz. Warszawa: PIW.

Duda, A. (2020). Nie pytają Cię o imię, walczą z ostrym cieniem mgły \#hot16challenge2. https:// www.youtube.com/watch?v=apghURJa_Bg [dostęp: 28.01.2021].

Fukuyama, F. (2009). Koniec historii, przeł. T. Bieroń, M. Wichrowski. Kraków: Znak.

Gomułowicz, A. (2018). Oblicze polskiej dyktatury. Nauka, 3/10, 67-80.

Kaufmann, J.-C. (2004). Ego. Socjologia jednostki. Inna wizja człowieka i konstrukcji podmiotu, przeł. K. Wakar. Warszawa: Oficyna Naukowa.

Kotkin, J. (2018). Powszechna historia miasta, przeł. A. Kunicka. Warszawa: Aletheia.

Malinowski, P. (2017). Profesor Adam Strzembosz: Ten projekt będzie listą hańby, Rzeczpospolita, 17 lipca. https://www.rp.pl/Sadownictwo/170719055-Profesor-Adam-Strzembosz-Tenprojekt-bedzie-lista-hanby.html [dostęp: 27.01.2021].

Mickiewicz, A. (1984). Dziady. Cześć III. Zakład Narodowy im. Ossolińskich.

Mikulski, J. (2017). Andrzej Zoll: To nie jest Trybunał, o którym mowa w konstytucji. Rzeczpospolita, 21 marca. https://www.rp.pl/Sadownictwo/170329730-Andrzej-Zoll-To-nie-jestTrybunal-o-ktorym-mowa-w-konstytucji.html [dostęp: 27.01.2021].

Mroziewicz, K. (2019). Delirium władzy. Warszawa: Fundacja Oratio Recta.

OKO.Press. (2017). Sędziowie nie mogą mieć połamanych kręgosłupów. Prof. Ewa Łętowska dla OKO.Press. 14 lipca 2017. https://oko.press/sedziowie-moga-miec-polamanych-kregoslupow-prof-ewa-letowska-dla-oko-press/ [dostęp: 27.01.2021].

Pannebaker, J.W. i Smyth, J.M. (2018). Terapia przez pisanie, przeł. A. Haduła. Kraków: Wydawnictwo Uniwersytetu Jagiellońskiego.

Piątek, M. (2020). Bez szumu. Polityka, 52(3293).

Llosa, M.V. (2010). Jak ryba w wodzie, przeł. D. Rycerz. Kraków: Znak.

Turner, J.H. (2004). Struktura teorii socjologicznych, przeł. G. Woroniecka i in. Warszawa: PWN.

Uchwała nr 129/2020 Państwowej Komisji Wyborczej z dnia 10 maja 2020 r. https://pkw.gov. pl/uploaded_files/1589173994_uchwala-nr-129.pdf [dostęp: 28.01.2021].

USTAWA z dnia 2 czerwca 2020 r. o szczególnych zasadach organizacji wyborów powszechnych na Prezydenta Rzeczypospolitej Polskiej zarządzonych w 2020 r. z możliwością głosowania korespondencyjnego, http://orka.sejm.gov.pl/opinie9.nsf/nazwa/368_u/\$file/368_ u.pdf [dostęp: 27.01.2021]. 


\section{SUMMARY}

\section{The story of how I became a political activist}

I'm going to tell you about how I became a political activist. What made me take to the streets, so I broke a taboo: political commitment? I put forward the thesis that in the present political system, participation in political life is abhorrent, so that it remains the domain of a narrow and permanent group of citizens who thus profit (in various dimensions) at the expense of the rest of society. I am talking / writing about how I interacted with other residents of Szczecin and what this experience was for me. I am not going to convince anyone of the so-called „my political option”. I argue that you should get involved, that this is the stage to full humanity.

KEYWORDS: politics, citizenship, democracy, commitment 